\title{
Tyrosine Crystals in Nasolabial Cyst - A Morphologic Curiosity Diagnosed at Cytology
}

\author{
Nazolabial Kistte Tirozin Kristalleri - Sitolojide Tanı \\ Konulan İlginç Bir Görünüm
}

Amita Krishnappa ${ }^{1}$

Vijay Shankar Shivashankar ${ }^{1}$

Sanjay Manchiah ${ }^{1}$

Abhishek Mandya Govindashetty ${ }^{1}$

${ }^{1}$ Department of Pathology, Adichunchanagiri Institute of Medical Sciences, BG

Nagara, Nagamangala taluk, Mandya district. Karnataka, India.

Geliş Tarihi/Received: 7 April 2019

Kabul Tarihi/Accepted: 7 June 2019

Address correspondence to: Vijay Shankar Shivashankar, Professor \& HOD AIMS, BG Nagara, Karnataka

e-mail: vijayshankarpatho@gmail.com

ORCID

Vijay Shankar Shivashankar

https://orcid.org/0000-0002-7768-6042

\begin{abstract}
Öz
Tirozinden zengin kristaller (TC), histopatolojide nadiren karșılașılan, sitolojide daha nadir görülen ilginc yapılardır. Bu kristaller, tükürük bezi, lakrimal bezin ve nadiren larinksin çeşitli neoplastik olmayan ve neoplastik lezyonlarında görülebilir. Nazolabial kistte bu kristallerin bulgusu bugüne kadar bildirilmemiştir. Nazolabial kistin klinik ve radyolojik tanısı ile 35 yaşında bir kadın hastaya ince iğne aspirasyon sitolojisi (FNAC) uygulandı. Tirozin kristalleri, az sayıda lenfosit ve histiositle birlikte, tekli ya da "petaloid' ve 'daisy head' formlarda gözlendi. Amilaz kristalleri de not edildi. Kesin nedene bakılmaksızın, TC'nin sitolojik olarak tanınması karışıklığı önlemek için önemlidir. Bu kristallerin FNAC'de tanınması sitopatologları tüm aspiratın titizlikle incelenmesi için uyarır. Bu yazı ayrıca, TC'nin oluşumunun nazolabial kist ile sınırlı olmadığını ve bunun bunun görülebileceği diğer durumları vurgulamaktadır.
\end{abstract}

Anahtar Kelimeler: Tirozin kristalleri, nazolabial kist, aspirat, sitoloji

\section{Abstract}

Tyrosine rich crystals (TC) are curious structures, rarely encountered at histopathology, more so at cytology. These crystals have been documented exceptionally in various non-neoplastic and neoplastic lesions of salivary gland, lacrimal gland and rarely in larynx. The finding of these crystals in nasolabial cyst has not been reported till date. A 35-year-old female with a clinical and radiologic diagnosis of nasolabial cyst underwent fine needle aspiration cytology (FNAC). Tyrosine crystals in singles and in groups assuming 'petaloid' and 'daisy head' forms were noted along with few lymphocytes and histiocytes. Amylase crystals were also noted. Regardless of the precise cause, cytologic recognition of TC is important to avoid confusion. Identification of these crystals at FNAC is a matter of avid observation and encourages cytopathologist for meticulous examination of all fluids. The case also highlights that the occurrence of TC is not restricted to SG and the circumstances in which it occurs is diversified.

Keywords: Tyrosine crystals, nasolabial cyst, aspirate, cytology

\section{INTRODUCTION}

TC are curious structures rarely encountered in salivary gland lesions. These crystals have been shown to occur in other tumours of head and neck region like retention cyst, meningiomas, ceruminous gland adenocarcinoma and cribriform adenocarcinoma of larynx (1). However, majority of published reports identify TC on histopathology.

Several hypotheses have been proposed for the formation of TC. In salivary gland, high content of tyrosine in saliva and or secretion and deposition over fibrous stroma, of some myoepithelium derived products elucidate the origin of TC. However, this theory does not hold true for occurrence of TC at other sites. Although several authors have studied the morphology, ultrastructure and histochemistry of these crystals, the exact cause of its occurrence is still an enigma. Moreover, their localization at diverse sites adds impasse to the understanding of its pathogenesis.

Nasolabial cyst is a rare developmental cyst accounting for $<1 \%$ of jaw cyst. TC have never been demonstrated in nasolabial cyst. Cytology reports of TC are very few (2-6). Identification of these crystals at FNAC is a matter of avid observation and encouragement for cytopathologist for meticulous examination of cyst fluids obtained at FNAC procedure.

\section{CASE}

42-year-old female presented with a chief complaint of swelling in between the nose and upper

Cite this article as: Amita K, Vijay SS, Sanjay M, Abhishek MG. Tyrosine 


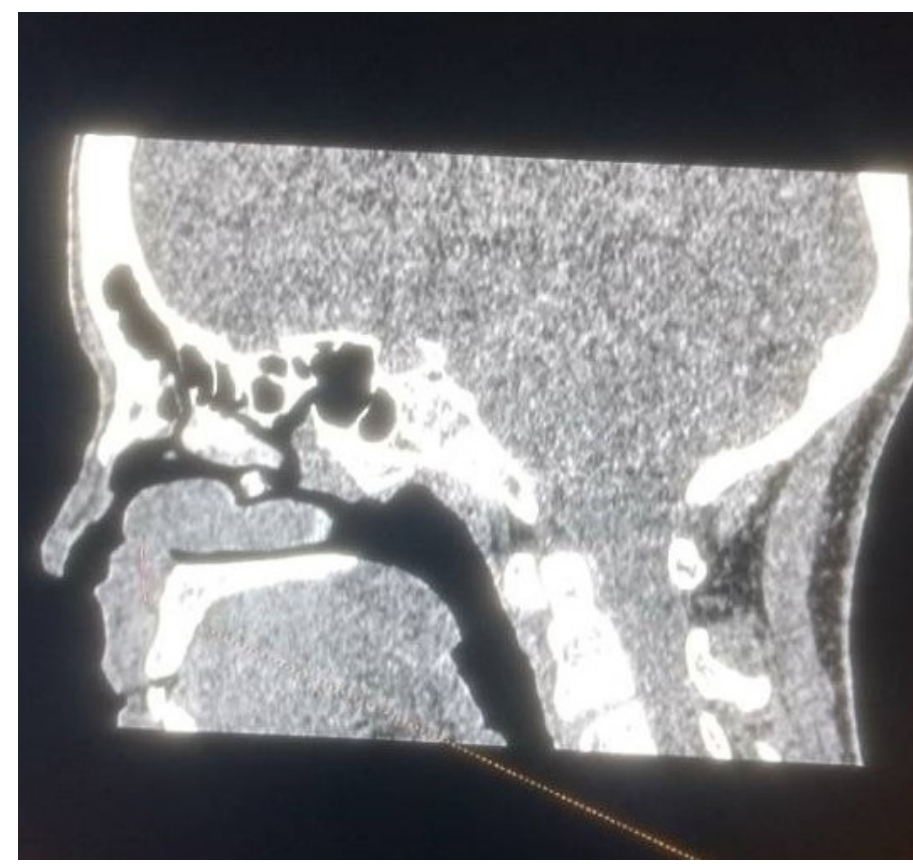

Figure 1. Computed Tomography scan showing awell defined mass with homogenous density in the lateral aspect of nasal region with the size of 1.5 $\mathrm{cm}$ in diameter.

lip on the right side. It was a slow growing swelling of one-year duration. The swelling was initially painless however patient complained of mild pain at the time of presentation. There was no history of trauma. On examination, there was a fullness noted near the right nasolabial fold with slight elevation of the ala of nose. On palpation, it was mildly tender. The intranasal and intraoral examination were unremarkable.

Computed tomography examination revealed well defined mass with homogenous density in the lateral aspect of nasal region with the size of $1.5 \mathrm{~cm}$

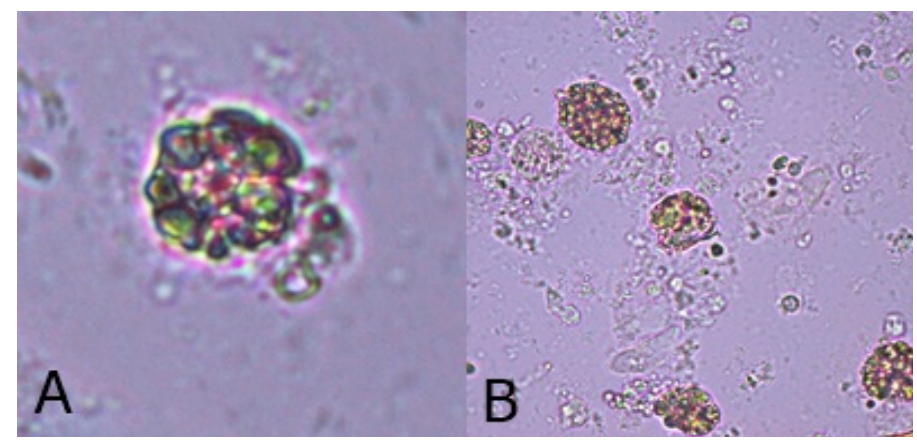

Figure 2. A \& B: Direct smears showing refractile flower like tyrosine crystals

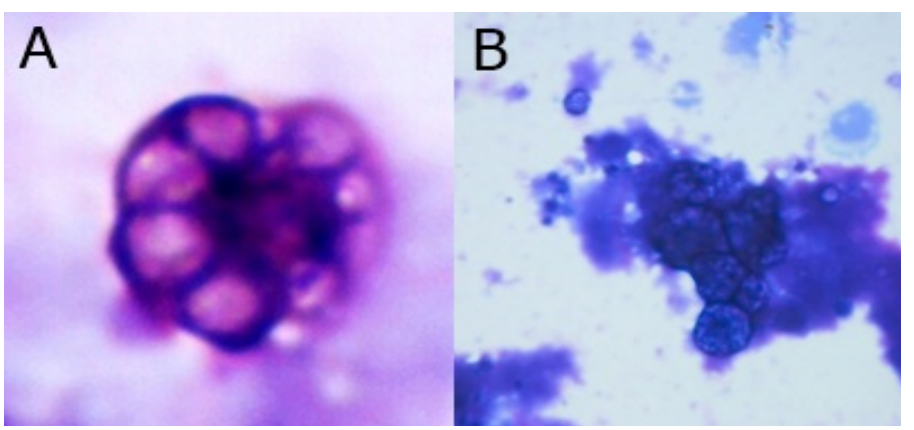

Figure 3. A \& B: FNAC smears showing 'petaloid' \& 'daisy head' tyrosine crystals in singles and groups respectively. (Giemsa, x 100)

in diameter. (Figure 1) The bone structures around it were unremarkable. A provisional diagnosis of nasolabial cyst was made. On FNAC, $1 \mathrm{ml}$ of clear fluid was aspirated. There was overflow of tears during the procedure of aspiration which continued for few minutes after the procedure. The swelling completely disappeared after aspiration. The fluid was subjected to direct smears as well as stained with haematoxylin \& Eosin and Giemsa stain.

FNAC smears showed crystals in singles and small groups. These crystals were eosinophilic in $\mathrm{H}$ \& $E$ stain and dark blue in giemsa stain. Few of the crystals were colourless in $\mathrm{H}$ \& $\mathrm{E}$ stain. The crystals assumed 'petaloid' and 'daisy head' configuration. Few lymphocytes, histiocytes and occasional epithelial cell clusters were noted in proteinaceous background. The crystals noted were morphologically consistent with tyrosine crystals reported in literature. Hence a final diagnosis of tyrosine crystals in nasolabial cyst was made. (Figure 2 to 4 )

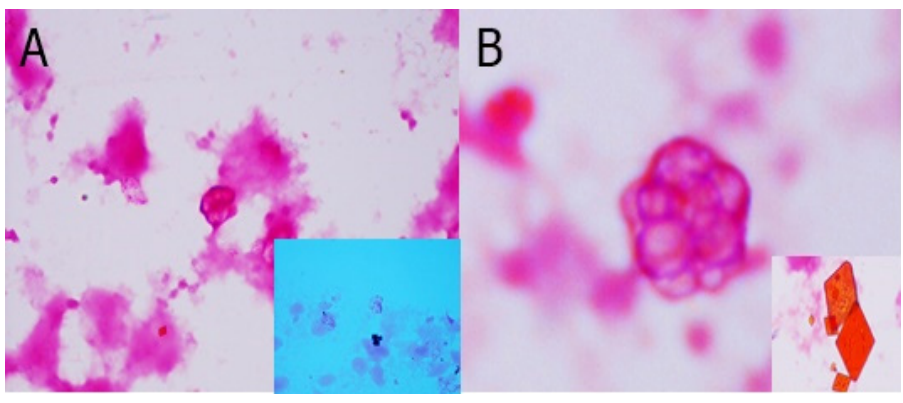

Figure 4. A \& B: FNAC smears showing 'petaloid' \& 'daisy head' tyrosine crystals in groups and singles respectively. (Hematoxylin \& Eosin x 100). Inset in 4 A shows colourless crystals. Inset in 4 B shows amylase crystals. 


\section{DISCUSSION}

Tyrosine crystal deposition is a rare and curious finding in cytology smears. A small number of cases have been reported, of which most were seen in association with salivary gland tumours, frequently pleomorphic adenoma. After the first description of TC in PA by Bullock et al in 1957, there have been very few case reports mentioning its occurrence in various non-neoplastic and neoplastic lesions at various sites in the body (7).

Nasolabial cyst (NLC) is a non-neoplastic cyst located in the naso alar region. It is a developmental entity arising either from the remnants of nasolacrimal duct or the epithelium in the mesenchyme after fusion of medial and lateral nasal process during the first month of foetal life. These cysts pose no harm except for a slow growing mass lesion with encroachment on surrounding structures if left untreated. In the present case, the swelling was impinging on the nasolacrimal duct causing obstruction (8). Aspiration of fluid during FNAC procedure, instantly relieved nasal obstruction and patient had tears flowing from the same eye. Differential diagnosis of nasolabial cyst includes odontogenic cyst, abscess, and soft tissue tumours. TC have never been documented in NLC.

TC have been reported to occur in the entire spectrum of salivary gland lesions, ranging from benign reactive lesions to malignant process. Saliva and normal salivary gland is rich in tyrosine which may exemplify the frequency of TC at this site. Most common lesion of salivary gland with $\mathrm{TC}$ is pleomorphic adenoma (PA). First description of TC in PA, at histopathology, was by Bullock et al in way back 1957 (7). Lemos LB et. Al., studied FNAC of 12 cases of PA and observed TC in 4 of them. The authors observed that TC showed fluoresce in ultraviolet light (3). Thomas K et al studied 113 cases of PA and observed TC in 24 cases, involving major and minor salivary glands at various sites. They also noted TC in case of carcinoma ex pleomorphic adenoma (9). Cambell WG et. Al., studied 130 pleomorphic adenomas in minor salivary glands wherein only one case unveiled TC (10). Warfried et. al., reported a case of bilateral PA of salivary gland subsequent to radiation therapy for Hodgkin's lymphoma in childhood. One of the PA which had received high dose of irradiation showed TC, favouring an association of local factors in formation of TC (11). Rare association with malignant salivary gland tumors, like polymorphous low grade adenocarcinoma are, on record (12).

Oncocytic lesions of salivary gland may harbour
TC. Gilcrease MZ et. Al., reviewed 97 oncocytic neoplasm and observed TC in 7 cases (14). Jamal et al described a case of oncocytic papillary cystadenoma with tyrosine crystals involving parotid gland in a 53-year-old male (6). The crystals were noted in FNAC smears and were confirmed by histopathology. The authors described them as tabular, petal form with blunt ends staining dark blue with giemsa and pale with pap stain. Occurrence of TC in benign retention cyst of parotid gland was reported by Carson et al. the authors reviewed eight cases of benign retention cyst over a duration of three years, wherein they could find TC in only two cases (1). Other than salivary gland lesions, TC tend to occur in chondroid syringoma of skin, clear cell and fibrous variant of meningioma, ceruminous gland tumour of external auditory canal and cribriform adenocarcinoma of lacrimal gland (1415).

The cause and effect of TC in various lesions in mystical. Production of some secretary products by myoepithelial cells and their deposition over collagen has been proposed as a mechanism of TC deposition in myoepithelium derived tumours. Other theories accent upon the excretion of tyrosine by some tumours and normal salivary gland. Some authors have observed higher prevalence of TC deposition in PA in blacks as compared to whites. They attribute this difference to the role of tyrosine in pigment metabolism. However, TC are not noted in patients with tyrosinemia. Nor these theories explain the presence of TC in other tumours in the body.

Morphologically TC have been described as refractile, pink eosinophilic with floret like arrangement. Other analogous terminologies are petal like, sun burst and daisy head appearance. At $H \& E, T C$ stain pink with yellow hue, while at Giemsa they take blue black colour. In Pap stained smears TC stain lighter. They may be scanty or numerous and usually seen in stromal area. Millon reaction gives a positive result, imparting red brown colour. Campbell et al, performed a detailed characterization of TC. Biochemical composition of TC is complex in that they were not only rich in tyrosine but also showed positive reaction for tryptophan, arginine and suphhydryl group (10). Regardless of the precise cause, cytologic recognition of TC is important to avoid confusion. Identification of these crystals at FNAC is a matter of avid observation and encourages cytopathologist for meticulous examination of all fluids. The case also highlights that the occurrence of TC is not restricted to $S G$ and the circumstances in which it occurs is 
diversified.

Conflict of interest: Authors declare that there is no conflict of interest between the authors of the article.

Financial conflict of interest: Authors declare that they did not receive any financial support in this study.

Address correspondence to: Vijay Shankar Shivashankar, Department of Pathology, Adichunchanagiri Institute of Medical Sciences, BG Nagara,Nagamangala taluk, Mandya district. Karnataka, India

E-mail: vijayshankarpatho@gmail.com

\section{REFERENCES}

1. Carson HJ, Raslan WF, Castelli MJ, et al. Tyrosine crystals in benign parotid gland cysts: Report of two cases diagnosed by fine-needle aspiration biopsy with ultrastructural and histochemical evaluation. Am J Clin Pathol 1994 ;102:699-2.

2. Bottles K, Ferrell LD, Miller TR. Tyrosine crystals in the FNA aspirates of pleomorphic adenoma of the parotid gland. Acta Cytol 1984;28:490-2.

3. Lemos LB, Baliga M, Brister T, et al. Cytomorphology of tyrosine-rich crystalloids in fine needle aspirates of salivary gland adenomas. Acta Cytologica 1997;41:1709-13.

4. Salem F, Siddiqui N. Tyrosine crystals in pleomorphic adenoma. Diagnostic Cytopathology 2006;34:419-20.

5. Handa U, Dhingra N, Chopra R, Mohan H. Pleomorphic adenoma: Cytologic variations and potential diagnostic pitfalls. Diagnostic Cytopathology 2009;37:11-5.
6. Musayev J, Önal B, Rahimov C, et al. Oncocytic papillary cystadenoma with tyrosine-rich crystalloids in the parotid: Case report with cytology and histology correlation and literature review. J Cytol Histol 2015;6:6.

7. Bullock WK. Mixed tumour of parotid gland with tyrosine crystals in the matrix. Anii J Clin Pathol 1953;23:1238-9.

8. Kajla P, Lata J, Agrawal R. Nasolabial cyst: Review of literature and a case report. J Maxillofac Oral Surg 2014;13:227-30.

9. Thomas K, Hutt MRS. Tyrosine crystals in salivary gland tumours. J Clin Pathol 1981;34:1003-5.

10. Campbell WG, Priest RE,Weathers DR. Characterization of two types of crystalloids in pleomorphic adenomas of minor salivary glands. A light-microscopic, electron-microscopic, and histochemical study. Am J Pathol 1985;118:194-202.

11. Warfield AT, Smallman LA. Simultaneous bilateral pleomorphic adenomas of the parotid glands with unilateral tyrosine rich crystalloids. J Clin Pathol 1994; 47(4):362-4.

12. Raubenheimer EJ, Willem FP, Van Heerden, et al. Tyrosine-rich crystalloids in a polymorphous low-grade adenocarcinoma. 1990:70;480-2.

13. Gilcrease MZ, Nelson FS, Guzman-Paz M. Tyrosine-rich crystals associated with oncocytic salivary gland neoplasms. Arch Pathol Lab Med 1998;122:644-9.

14. Constantinescu MB, Chan JB, Cassarino DS. Chondroid syringoma with tyrosine crystals: Case report and review of the literature. Am J Dermatopathol 2010;32:171-4.

15. Schollenberg E, Easton AS. A case of clear cell meningioma with tyrosine-rich crystals. Int J Surg Pathol 2013;21:411-2. 